Kamil Frymark

Warszawa

\title{
MOCARSTWA WSCHODZĄCE W POLITYCE ZAGRANICZNEJ RFN
}

\section{Wstęp}

Niemieckie poszukiwanie pozaeuropejskich partnerów jest zjawiskiem stosunkowo nowym, uwypuklonym przede wszystkim przez kryzys gospodarczy. Jednocześnie w ostatnim czasie coraz częściej pojawiają się głosy (niemieckich polityków, naukowców i komentatorów życia politycznego), że Berlin powinien w większym stopniu przewodzić wspólnocie międzynarodowej, co odpowiadałoby jego realnej sile mierzonej przede wszystkim wielkością gospodarki ${ }^{1}$. W celu wypełnienia tego postulatu RFN wypracowała koncepcję skoordynowanego podejścia do mocarstw wschodzących. W poniższym artykule autor chciałby skupić się przede wszystkim na motywach wypracowania tej strategii oraz wskazaniu kilku kluczowych problemów wynikających z miejsca mocarstw wschodzących w polityce zagranicznej RFN.

\section{Mocarstwa wschodzące}

Przedstawienie przez RFN koncepcji dotyczącej Gestaltungsmächte (mocarstw wschodzących) stwarza m.in. problem definicyjny, gdyż de facto chodzi o „mocarstwa kształtujące” rzeczywistość międzynarodową, których wpływ na przyszłe stosunki międzynarodowe, w tym przede wszystkim na ich gospodarczy aspekt będzie rósł. Koncepcja „Kształtować globalizację - rozbudowywać partnerstwa - dzielić odpowiedzialność" 2

${ }^{1}$ Por. Wirtschaft macht Außenpolitik, Süddeutsche Zeitung, 2. Januar 2013, s. 2.; Welt ohne Führung. Wie viel Deutschland erträgt Europa?, Süddeutsche Zeitung, 2. Januar 2013, s. 4.

${ }^{2}$ Globalisierung gestalten - Partnerschaften ausbauen - Verantwortung teilen. Konzept der Bundesregierung, Auswärtiges Amt, Berlin 2012. 
odnosi się do państw, z którymi RFN planuje zwiększenie wielopoziomowej współpracy w najbliższych latach.

Jako mocarstwa wschodzące strategia określa państwa posiadające silną i obdarzoną dużym potencjałem gospodarkę, wykazujące chęć większej aktywności w polityce międzynarodowej a jednocześnie mające znaczenie dla procesów globalizacyjnych i regionalnych. Strategia nie ogranicza listy państw, do której jest skierowana i wymienia m.in. Brazylię, Wietnam, Malezję, Meksyk, Indonezję, Nigerię, Kolumbię oraz Angolę. Stanowi jednocześnie uzupełnienie wobec dotychczas prezentowanych przez RFN stanowisk wobec regionu Ameryki Południowej, Afryki i Azji. Z zapisów strategii wynika również, iż będzie ona w praktyce korespondowała z koncepcją strategicznego partnerstwa Unii Europejskiej z Chinami, Indiami, Brazylia, Meksykiem i Afryką Południową ${ }^{4}$.

Przygotowanie koncepcji Kształtować globalizacje jest wynikiem rozpoznania przez niemieckie Ministerstwo Spraw Zagranicznych nowych tendencji w zmieniającym się otoczeniu międzynarodowym. Przypisywanie coraz większej roli państwom Południa oraz próba pozyskania ich potencjału dla realizacji niemieckich interesów politycznych jest elementem dopasowania niemieckiej polityki zagranicznej do wyzwań globalizacji. Brak sztywnego podziału na resortowe prowadzenie polityki zagranicznej skłonił Berlin do opracowania spójnego programu współpracy z nowymi potęgami wschodzącymi ${ }^{5}$. W jej ramach Niemcy przygotowały sześć obszarów tematycznych, w których będzie prowadzony dialog strategiczny z mocarstwami wschodzącymi. Zalicza się do nich bezpieczeństwo międzynarodowe, prawa człowieka, gospodarkę i finanse, problematykę surowcową i energetyczną, pracę i kwestie socjalne oraz szeroko pojęty rozwój.

Kwestie bezpieczeństwa $\mathrm{w}$ omawianym dokumencie są poruszane przez RFN z perspektywy multilateralności prowadzonej polityki zagranicznej. Wskazuje się na uczestnictwo w NATO i UE jako podstawowe filary niemieckiego bezpieczeństwa. Celami współpracy z mocarstwami wschodzącymi w ramach tej polityki ma być przede wszystkim zapobieganie konfliktom, rozwiązywanie już istniejących oraz wzmacnianie regionalnych struktur bezpieczeństwa, tak by wspierane państwa mogły przejmować większą część odpowiedzialności za dany region ${ }^{6}$. Jednym

${ }^{3}$ A. Ciechanowicz, K. Popławski, Niemiecka koncepcja zwiększenia korzyści gospodarczych z globalizacji, BEST OSW, nr 9(210).

${ }^{4}$ Por. Globalisierung gestalten, op. cit., s. 9.

${ }^{5}$ Por. E. Sandschneider, Deutschland: Gestaltungsmacht in der Kontinuitätsfalle, Aus Politik und Zeitgeschichte, 10/2012. s. 3.

${ }^{6}$ Przykładem jest współpraca RFN z RPA. Por. http://www.southafrica.diplo.de/contentblob/3518878/Daten/2306777/BNKJointCommunique.pdf [data wejścia: 21.06.2012]. 
z elementów budowania pokoju i bezpieczeństwa jest zdaniem strony niemieckiej powiększanie obszarów wolnych od skutków klęsk żywiołowych oraz innych katastrof. Środkiem do jego osiągnięcia jest udzielanie pomocy humanitarnej dla regionów pogrążonych w chaosie i niepotrafiących samodzielnie rozwiązać zaistniałej sytuacji. RFN postuluje większe zaangażowanie mocarstw wschodzących $\mathrm{w}$ tworzenie mechanizmów takiej pomocy ${ }^{7}$.

Drugą zasadniczą kategorią poruszaną w koncepcji jest promowanie standardów praw człowieka oraz rządów prawa w państwach nowych potęg. Jednocześnie zwraca się uwagę, iż należy w większym niż dotychczas stopniu uwzględnić kulturowe aspekty podejścia do zagadnień praw człowieka ${ }^{8}$. W odniesieniu do rynków finansowych i współpracy gospodarczej projekt niemieckiego MSZ mówi o konieczności zwiększania integracji w ramach Światowej Organizacji Handlu (WTO) oraz wprowadzenia podobnych standardów w dziedzinie eksportu w państwach adresatach dokumentu9. Niemcy podkreślają w przygotowanej strategii chęć bliższej współpracy z mocarstwami wschodzącymi w zakresie energii, $w$ tym $w$ ramach agencji IRENA. Kładą również zdecydowany nacisk na bezpieczne wykorzystywanie energii atomowej oraz podkreślają gotowość bliższej współpracy $\mathrm{w}$ ramach przygotowywania programów przechodzenia poszczególnych państw z tradycyjnej struktury energetycznej na model wykorzystujący przede wszystkim odnawialne źródła energii $(\mathrm{OZE})^{10}$. W ramach postulatów odnośnie rynku pracy RFN oferuje ułatwiony dostęp do rynku wewnętrznego UE państwom, które będą spełniały wymogi $\mathrm{w}$ dziedzinie prawa pracy i europejskich standardów $\mathrm{w}$ tym zakresie ${ }^{11}$. Berlin kładzie także nacisk na pogłębienie kooperacji w dziedzinie współpracy (nie pomocy - sic!) rozwojowej. Chodzi zarówno o przejmowanie „większej odpowiedzialności" przez mocarstwa wschodzące, jak również o przejrzystość reguł w podejmowanej współpracy, z uwzględnieniem takich elementów jak prawa człowieka, praworządność czy ochrona klimatu' ${ }^{12}$.

W dokumencie przygotowanym przez Auswärtiges Amt, Niemcy oferują swoim nowym partnerom przede wszystkim szeroko pojęty know-how ze wszystkich omawianych obszarów oraz lobbing w instytucjach współpracy wielostronnej, takich jak WTO, G20 czy UE, w tym ułatwienia handlowe na terytorium państw Unii. Do szczegółowych form

\footnotetext{
${ }^{7}$ Por. Globalisierung gestalten, op. cit., s. 25.

${ }^{8}$ Por. Ibidem, s. 28.

9 Por. Ibidem, s. 33-37.

10 Por. Ibidem, s. 39-43.

11 Por. Ibidem, s. 47.

12 Por. Ibidem, s. 51-52.
} 
współpracy Niemcy zaliczają: konsultacje z poszczególnymi państwami, tworzenie nowych oraz pobudzenie aktywności obecnie istniejących grup tematycznych, strategiczne partnerstwo pomiędzy UE a wybranymi mocarstwami wschodzącymi jako forma dodatkowego pogłębienia relacji, fora sektoralne oraz rozszerzenie dotychczasowych spotkań nieformalnych lub półoficjalnych pomiędzy przedstawicielami polityki, gospodarki i think-tanków z państw GIBSA: Brazylii, Indii, RPA oraz Niemiec na nowe państwa ${ }^{13}$.

\section{Przesłanki polityczne poszukiwania nowych partnerów}

Chęć poszukiwania nowych partnerów dla realizacji celów niemieckiej polityki zagranicznej wynika z szeregu przesłanek składających się zarówno na historyczne uwarunkowania niemieckiego zaangażowania międzynarodowego jak i ocenę współczesnego środowiska międzynarodowego.

\section{Multilateralizm}

Przede wszystkim Niemcy po zjednoczeniu i uzyskaniu na mocy traktatu moskiewskiego (12.09.1990 r.) pełni suwerenności rozpoczęły proces emancypacji w polityce międzynarodowej. Dotyczy to $\mathrm{w}$ największym stopniu polityki europejskiej oraz polityki bezpieczeństwa ${ }^{14}$. Jednym z przejawów tej polityki jest chęć odgrywania coraz większej roli w polityce międzynarodowej. W celu umotywowania własnego dążenia do zdobywania coraz większego wpływu, RFN wykorzystuje teorię multilateralizmu rozumianego jako współpracę trzech lub więcej państw bazującą na niedyskryminacji aktorów biorących w niej udział oraz przestrzeganiu wzajemnie ustalonych norm i zasad ${ }^{15}$. Wynika to m.in. z historycznych uwarunkowań Westbindung i pryncypiów integracji europejskiej, świadomości braku wystarczającej siły do działania unilateralnego oraz rzeczywistego przekonania o korzyściach (w tym gospodarczych i wizerunkowych)

${ }^{13}$ Por. Ibidem, s. 55-58.

${ }^{14} \mathrm{Na}$ ten temat dostępna jest bogata literatura m.in. K. Malinowski, Przemiany niemieckiej polityki bezpieczeństwa 1990-2005, Poznań 2009; U. Roos, Eine Rekonstruktion der grundlegenden Handlungsregeln, Wiesbaden 2010; R. Meier-Walser, A. Wolf (Hrsg.), Die Außenpolitik der Bundesrepublik Deutschland. Anspruch, Realität, Perspektiven, München 2012; Nowa Europa Przegląd Natoliński, nr 1 (12)/2012.

${ }^{15}$ Więcej na temat teorii multilateralizmu w niemieckiej polityce zagranicznej zob. R. Baumann, The Transformation of German Multilateralism. Changes in the Foreign-Policy Discourse since Unification, German Politics and Society, vol. 20, no. 4 (Winter 2002), http://www. soz.uni-frankfurt.de/hellmann/mat/baumann_gps_multilateralism.pdf [dostęp: 10.11.2012]. 
płynących z polityki opartej na zasadach współpracy wielostronnej ${ }^{16}$. Przekonanie o słuszności prowadzenia takiej polityki wyraził m.in. były minister spraw zagranicznych RFN Joschka Fisher twierdząc w czerwcu 2002 roku, iż rozwiązanie najważniejszych problemów globalnych jest możliwe wyłączenie „przez multilateralizm, to znaczy we współpracy z innymi narodami"17. Jednocześnie Niemcy motywują swoje zaangażowanie w strukturach współpracy wielostronnej poprzez zwiększanie własnej odpowiedzialności za ład międzynarodowy. Takie podejście zawiera również chęć przejmowania większego wpływu na zagadnienia polityczne i bezpieczeństwa ${ }^{18}$; m.in. $\mathrm{w}$ tym celu stworzono koncepcję mocarstw wschodzacych, która ma stanowić narzędzie do wywierania większego wpływu na aktorów w niej uczestniczących.

Niemieckie podejście jest dobrze widoczne na płaszczyźnie zaangażowania $w$ organizacjach międzynarodowych. W ramach ONZ Niemcy od początku lat 90. próbują dokonać zmiany układu sił na korzyść państw aspirujących do Rady Bezpieczeństwa motywując to gotowością wniesienia większego wkładu w stabilizowanie ładu międzynarodowego. Koncepcja mocarstw wschodzacych dotyczy również wspólnego lobbowania państw na rzecz reformy RB ONZ a tym samym służy realizacji niemieckich postulatów w tym zakresie.

\section{Przewartościowanie polityki amerykańskiej}

Jedną z podstawowych przesłanek stworzenia koncepcji skierowanej do mocarstw wschodzących jest przewartościowanie polityki amerykańskiej w kierunku Azji Południowo-Wschodniej. Wymusza to na pozostałych

${ }^{16}$ Częścią motywacji niemieckiego zaangażowania w ramach współpracy z nowymi mocarstwami wschodzącymi jest niemiecka retoryka wartości, podkreślana również w podejściu do nowych mocarstw wschodzących. W reakcji na kryzysu w UE, niemieckie MSZ stworzyło koncepcję komunikowania w sprawie własnego stanowiska w toku reformowania Unii Europejskiej, gdzie podkreśla się przywiązanie do wartości, które są jednym z podstawowych determinantów działania RFN na płaszczyźnie europejskiej. Por. Europa erklären - Europa diskutieren. Ein Konzept für die Europa-Kommunikation 2012, Auswärtiges Amt, Februar 2012, http://www.auswaertiges-amt.de/cae/servlet/contentblob/610174/ publicationFile/165161/120229_Strategie_Europakommunikation.pdf [dostęp: 14.11.2012].

${ }^{17}$ Cyt. za: G. Hellmann, Ch. Weber, F. Sauer (Hrsg.), Die Semantik der neuen deutschen Außenpolitik. Eine Analyse des außenpolitischen Vokabulars seit Mitte der 1980er Jahre, Wiesbaden 2008, s. 116.

${ }^{18}$ Sformułowania przejmowanie „większej odpowiedzialności” używano w różnym kontekście po zjednoczeniu RFN i rozszerzano je na kolejne obszary polityki zagranicznej Niemiec (od zaangażowania w organizacjach międzynarodowych - szczególnie ONZ, po działania w UE). Por. G. Hellmann, Ch. Weber, F. Sauer (Hrsg.), Die Semantik, op. cit., s. 164-171. 
aktorach intensywniejsze zaangażowanie się $\mathrm{w}$ tym regionie oraz poszukiwanie (de facto $\mathrm{w}$ roli rywala USA) partnerów dla dalszego rozwoju stosunków gospodarczych i politycznych. Rodzi to ponadto nową sytuację $\mathrm{w}$ bilateralnych stosunkach niemiecko-amerykańskich. Podczas gdy RFN chce realizować własne interesy w sferze ekonomicznej, USA próbuje utrzymać swoją dominację geopolityczną. Pomimo tego Niemcy chcą nadal pogłębiać transatlantyckie relacje $\mathrm{w}$ dziedzinie bezpieczeństwa rozwijając jednocześnie stosunki handlowe z $\mathrm{ChRL}^{19}$. Ten dylemat będzie obciążał w przyszłości stosunki transatlantyckie.

\section{Wzrost znaczenia Chin w polityce Niemiec}

Stosunki niemiecko-chińskie skupiają się przede wszystkim na symbiozie dwóch elementów: Niemcy w zamian za przekazywane chińskim przedsiębiorstwom know-how własnych technologii, otrzymują rynek zbytu, który rekompensuje recesję w Europie. RFN od dłuższego czasu obserwuje dynamiczny wzrost potęgi Pekinu ${ }^{20}$ jednak intensyfikacja współpracy nastąpiła dopiero w czerwcu 2011 r., gdy doszło do pierwszych międzyrządowych konsultacji ${ }^{21}$. W ich następstwie poszerzono przede wszystkim kooperację gospodarczą podkreślając również chęć ściślejszych uzgodnień $\mathrm{w}$ zakresie polityki finansowej (m.in. poprzez współpracę banków centralnych). Końcowe oświadczenie zawiera także perspektywę wzrostu obrotów handlowych do 2015 r. do poziomu $200 \mathrm{mld}$ euro $^{22}$ (2010 - 130 mld euro). W 2011 roku udział niemieckiego eksportu do Chin w ramach całego eksportu europejskiego wynosił $47,4 \%$ natomiast niemiecki import wynosił 22\%. Jednocześnie Chiny były dla RFN piątym najważniejszym celem eksportu i drugim krajem importowym (po Holandii) ${ }^{23}$. Obrazuje to wagę stosunków z Chinami, od 2010 r. oficjalnie nazywanymi „strategicznym partnerstwem”. Drugie konsultacje rządo-

${ }^{19}$ Por. I. Bremmer, M. Leonard, U.S.-German relationship on the rocks, http://ecfr.eu/ content/entry/commentary_u.s._german_relationship_on_the_rocks [dostęp: 14.11.2012].

${ }^{20}$ Więcej o historii współpracy RFN z mocarstwami wschodzącymi oraz zestawienie obszarów współpracy z mocarstwami współkształtującymi w przyszłości ład międzynarodowy w: J. Husar, G. Mainhold, S. Mair (Hrsg.), Neue Führungsmächte: Partner deutscher Außenpolitik?, Baden-Baden 2009.

${ }^{21}$ Ten rodzaj współpracy jest zagwarantowany dla najważniejszych partnerów RFN: Francji, Włoch, Hiszpanii, Rosji, Izraela (od 2008), Indii (od 2011), Polski, Chin (od 2011).

${ }^{22}$ Por. Gemeinsame Erklärung anlässlich der 1. Deutsch-Chinesischen Regierungskonsultationen in Berlin, Presse- und Informationsamt der Bundesregierung,28. Juni 2011, http://www.bundesregierung.de/Content/DE/Pressemitteilungen/BPA/2011/06/201106-28-deutsch-chin-regkonsultationen.html [dostęp 05.11.2012].

${ }^{23}$ Deutsch-Chinesische Wirtschaftsbeziehungen. Eine strategische Partnerschaft zum beiderseitigen Nutzen, Monatsbericht 09-2012, BMWI, s. 2., http://www.bmwi.de/Dateien/BMWi/ 
we odbyły się w sierpniu 2012 r. i były potwierdzeniem dotychczasowego rozwoju obustronnych relacji.

Podstawowym problemem $\mathrm{w}$ relacjach gospodarczych jest wykorzystywanie niemieckich rozwiązań technicznych przez chińskie firmy zakładające spółki joint venture z niemieckimi odpowiednikami, co jest wymogiem dla większości inwestycji zagranicznych w Państwie Środka i tworzenie własnych produkcji opartych na niemieckich modelach. Powoduje to znaczący wzrost napięcia i domagania się ze strony niemieckiej wprowadzenia środków ochronnych przeciwko nieuczciwej konkurencji (dumpingowym cenom m.in. w przemyśle fotowoltaicznym) przy czym takie kroki pociągną prawdopodobnie identyczną reakcję strony chińskiej na inne towary ${ }^{24}$.

Drugim istotnym ograniczeniem relacji niemiecko-chińskich jest reglamentowanie przez Pekin eksportu metali ziem rzadkich. Bez tych surowców nie jest możliwe wytwarzanie najwyższych technologii, co umożliwia Chinom monopolizację niektórych gałęzi przemysłu ${ }^{25}$. Ta strategia rządu chińskiego była jedną z przyczyn zawarcia przez RFN partnerstwa surowcowego z Kazachstanem i Mongolią oraz szerszego rozpatrywania nowych mocarstw wschodzących jako przyszłych dostawców najważniejszych surowców technologicznych ${ }^{26}$. W 2012 roku UE, USA i Japonia złożyły do WTO wspólną skargę na restrykcyjną politykę Pekinu wobec eksportowania metali ziem rzadkich.

Niemieckie partnerstwo strategiczne $\mathrm{z}$ Chinami nie ogranicza się jednak wyłącznie do stosunków gospodarczych. Wykracza ono poza te relacje i wraz ze wzmocnieniem pozycji RFN w Europie w wyniku kryzysu strefy euro i utraty dotychczasowej pozycji przez pozostałe państwa (głównie Francję, Włochy, Hiszpanię i UK) będzie ono nabierało coraz większego znaczenia także w kontekście relacji chińsko-unijnych. Dowodzi tego wizyta Angeli Merkel w Pekinie w przeddzień 14 szczytu EUChiny z 14 lutego 2012 r. omawiająca de facto najważniejsze zagadnienia $\mathrm{z}$ agendy europejskiej ${ }^{27}$.

PDF/Monatsbericht/Auszuege/09-2012-I-4, property=pdf,bereich=bmwi2012, sprache=de,r wb=true.pdf [dostęp 05.11.2012].

${ }^{24}$ Por. Deutschland AG macht China seine Aufwartung, 30.08.2012, http://www.handelsblatt.com/unternehmen/industrie/reise-nach-fernost-deutschland-ag-macht-china-seine-aufwartung-seite-all/7067304-all.html [dostęp 05.11.2012].

${ }^{25}$ S.-A. Mildner, F. Wassenber, Immer knapper, immer teurer? Die Importabhängigkeit bei metallischen Rohstoffen schafft Verwundbarkeiten, Internationale Politik, November/Dezember 2009, s. 52-58.

${ }^{26}$ A. Kwiatkowska-Drożdż, Deficyt surowców naturalnych - implikacje dla niemieckiej polityki, Komentarze OSW, Numer 46, luty 2011.

27 Podobna sytuacja miała miejsce w przypadku 15 szczytu UE-Chiny, gdy 20 września 2012 r. odbyły się konsultacje europejsko-chińskie, a 30 sierpnia 2012 r. doszło do drugiego spotkania rządu Angeli Merkel i Wen Jiabao. 


\section{Gospodarcze przesłanki poszukiwania nowych partnerów}

\section{Kryzys w strefie euro}

Niemcy jako największa gospodarka Europy jest uzależniona od prowadzenia gospodarki eksportowej. Do momentu wybuchu kryzysu gospodarczego w 2008 r. głównymi kierunkami niemieckiego eksportu była Unia Europejska (na dziesięć głównych niemieckich celów eksportowych osiem pochodziło z UE a eksport do nich wynosił w 2007 r. 480,1 mld euro) oraz Stany Zjednoczone (2007: 73,4 mld euro ${ }^{28}$. W momencie wybuchu kryzysu Niemcy były zmuszone do poszukiwania nowych partnerów w celu uzupełnienia straty dotychczasowego wolumenu eksportu. Podstawowym kierunkiem nowej współpracy gospodarczej były Chiny oraz Rosja, co pozwoliło na relatywnie szybkie przezwyciężenie tendencji spadkowej w niemieckiej gospodarce i od 2010 r. umożliwiło szybszy rozwój. Widać to szczególnie na przykładzie dynamiki eksportu ukierunkowanego na państwa BRIC (Brazylia, Rosja, Indie, Chiny). W przypadku Chin wzrost wyniósł 95\%, Brazylii 76\%, a Indii $45 \%{ }^{29}$. Kontynuację tego trendu widać również w późniejszym okresie przy czym dynamika eksportu do Chin była najwyraźniejsza. W roku 2011 eksport do państw BRICS wynosił 130 mld euro natomiast do USA 74 mld euro ${ }^{30}$. Utrzymanie tego trendu będzie jednym z kluczowych wyzwań dla niemieckiej gospodarki w najbliższym czasie, szczególnie w kontekście zmieniających się prognoz gospodarki chińskiej ${ }^{31}$.

\section{Bezpieczeństwo surowcowe}

Rozwój gospodarczy RFN jest możliwy dzięki dostępności i gwarancji stabilności dostaw surowców, które umożliwiają eksportowanie wysokoprzetworzonych produktów i w ten sposób wytwarzanie znacznej części niemieckiego PKB. Niemcy starają się od kilku lat powiązać działania go-

${ }^{28}$ Dane za: Statistisches Bundesamt, 2008, Das sind Deutschlands wichtigste Handelspartner, http://www.spiegel.de/wirtschaft/export-import-das-sind-deutschlands-wichtigste-handelspartner-a-541991.html

${ }^{29}$ K. Popławski, Niemcy zwiększaja wspótpracę handlowa z gospodarkami wschodzacymi, BEST OSW, 7 (167), 2011, s. 2-4.

${ }^{30}$ G. Erber, M. Schrooten, BRICS: Deutschland profitiert vom Wachstum in Brasilien, Russland, Indien, China und Südafrika - Wie lange noch?, DIW Wochenbericht Nr 34.2012, s. 8.

${ }^{31}$ Por. Das große Aber, http://www.zeit.de/2012/46/Deutschland-Wirtschaft-Konjunktur-Krise [dostęp 16.11.2012] oraz T. Straubhaar, Die chinesische Konterrevolution, HWWI Standpunkt, 9. November 2012, http://www.hwwi.org/uploads/tx_wilpubdb/HWWI_ Standpunkt_195.pdf [dostęp: 16.11.2012]. 
spodarcze wraz z politycznymi, zarówno poprzez uwypuklenie problemu deficytu surowców w dyskursie publicznym jak również przez konkretne działania polityczne w celu dywersyfikacji dostawców surowców (chodzi przede wszystkim o surowce energetyczne oraz metale ziem rzadkich). W tym kontekście można zaobserwować wzrastające znaczenie państw pozaeuropejskich, w tym szczególnie azjatyckich i afrykańskich dla niemieckiej polityki surowcowej, co będzie przekładało się na politykę zagraniczną i działania Bundeswehry ${ }^{32}$.

Przykładem nowych tendencji w polityce zagranicznej RFN jest zawieranie partnerstw surowcowych. Powoduje to dysonans pomiędzy postulowaną przez Niemcy "Europą wartości”33 i promowaniem przez nie na arenie międzynarodowej idei praw człowieka a bieżącą Realpolitik. Powyższe rozbieżności widać szczególnie wyraźnie na przykładzie polityki wobec państw bogatych w zasoby surowcowe. W październiku $2010 \mathrm{r}$. rząd koalicji CDU/CSU-FDP przyjął strategię wspierania niemieckich firm w pozyskiwaniu surowców. Realizacją tej strategii jak dotychczas są dwie umowy: z Mongolią (13.10.2011) oraz z Kazachstanem (08.02.2012). W drugim przypadku mowa jest o zawiązaniu partnerstwa surowcowego, co ma w przyszłości zdywersyfikować dostawy surowców ziem rzadkich do Niemiec $^{34}$. Warto dodać, że motyw gospodarczy był uzupełniony elementem geostrategicznym. Mongolia dążyła bowiem do zbliżenia z RFN ze względu na położenie pomiędzy Rosją i Chinami i poszukiwała nowego partnera jako balansu dla regionalnego układu sił.

${ }^{32}$ Chodzi tu przede wszystkim o pomijanie w rozmowach tematyki praw człowieka z partnerami handlowymi (vide: ChRL, Kazachstan) oraz dodanie do nowych obowiązków Bundeswehry ochrony dróg handlowych oraz podkreślanie w tym kontekście stabilności dostaw surowców. Por. Peak oil, Sicherheitspolitische Implikationen knapper Ressourcen, Zentrum für Transformation der Bundeswehr, http://www.bundeswehr.de/resource/resource/ MzEzNTM4MmUzMzMyMmUzMTM1MzMyZTM2MzIzMDMwMzAzMDMwMzAzMDY4Mzg2ZjY2Nzk2NzYxNzcyMDIwMjAyMDIw/Sicherheitspolitische\%20Implikationen\%20knapper\%20Ressourcen.pdf [dostęp: 18.11.2012]; Westerwelle will Rohstoff-Interessen schützen, WirtschaftsWoche, http://www.wiwo.de/politik/deutschland/aussenpolitik-westerwelle-will-rohstoff-interessen-schuetzen/6147924.html [dostęp18.11.2012], Bundeswehr soll freien Zugang zu Rohstoffen sichern, Bundeswehr Monitoring, http://www.bundeswehr-monitoring.de/auftrag-und-struktur/bundeswehr-soll-freien-zugang-zu-rohstoffen-sichern-11796.html [dostęp: 18.11.2012], J. Gotkowska, Bundeswehra 3.0, Polityczny, wojskowy i społeczny wymiar reformy sił zbrojnych RFN, OSW, Punkt Widzenia 28, Warszawa, maj 2012.

${ }^{33}$ Koncepcja przygotowana przez AA mająca na celu przybliżenie europejskiej polityki Niemiec; jej znaczna część odnosi się do wartości promowanych przez RFN na arenie międzynarodowej i w ramach UE. Por. Europa erklären - Europa diskutieren. Ein Konzept für die Europa-Kommunikation 2012, Auswärtiges Amt, Berlin, Februar 2012.

34 Por. K. Frymark, Niemieckie wspótksztattowanie globalizacji w dobie kryzysu, Biuletyn Niemiecki, nr 31, 31.10.2012, s. 6-8. 
Specjalne stosunki gospodarcze i polityczne doprowadziły do stworzenia koncepcji Partnerstwa dla Modernizacji z Rosją ${ }^{35}$. Początkowa idea (stworzona i zrealizowana przede wszystkim przez zaangażowanie RFN) pogłębienia relacji unijno-rosyjskich była wielostopniowa i miała dotyczyć zarówno budowania elementów społeczeństwa obywatelskiego, wzmocnienia funkcjonowania państwa prawa, modernizacji administracji, jak i poprawienia klimatu inwestycyjnego. Element stricte surowcowy był wyłącznie jednym z punktów współpracy w ramach nowej formuły nie zaś jej fundamentalnym paradygmatem, a samo Partnerstwo miało rozszerzyć dotychczasowe płaszczyzny współpracy poza temat surowców ${ }^{36}$. Jednak wraz z brakiem postępów po stronie rosyjskiej oraz negatywnym nastawieniem RFN do dalszego wspierania europejskiego projektu Partnerstwa przekształca się ono we współpracę surowcową. Jednocześnie Berlin jest coraz bardziej przeświadczony o ograniczonej zdolności Rosji do wewnętrznej zmiany i nakierunkowuje współpracę całkowicie na kwestie gospodarcze w tym przede wszystkim energetyczne ${ }^{37}$. Stabilność dostaw surowców energetycznych, w tym gazu z Rosji, jest szczególnie istotna $\mathrm{w}$ perspektywie dokonywanej się $\mathrm{w}$ RFN transformacji energetycznej (Energiewende). Przejście na korzystanie z OZE oraz wyłączenie elektrowni atomowych do końca 2022 r. wymusza zabezpieczenie konwencjonalnych źródeł produkcji prądu przy jednoczesnym realizowaniu strategii redukcji emisji gazów cieplarnianych. $Z$ tego punktu widzenia gaz ziemny jest obecnie najkorzystniejszym surowcem, co wzmacnia kooperację niemiecko-rosyjską.

\section{Eksport technologii OZE}

Poszukiwanie nowych partnerów wśród mocarstw wschodzących wynika także z chęci eksportowania do tych państw nowoczesnych technologii energetycznych jako następstwa przeprowadzenia przez RFN

${ }^{35}$ J. Gotkowskia, „Partnerstwo na rzecz modernizacji” - oferta RFN dla Rosji Miedwiediewa z korzyścia dla niemieckiego biznesu, Tydzień na Wschodzie, OSW, 18 (52), 2008, s. 5-7.

${ }^{36}$ B. Koszel, Partnersto dla Modernizacji - niemiecki sukces, czy porażka?, Instytut Zachodni, Nr 54/2011, s. 2-3.

37 Por. J. Gotkowska, Niemiecko-rosyjskie Partnerstwo dla modernizacji - poniżej dużych oczekiwań RFN i Rosji, Tydzień na Wschodzie, OSW, Nr 25(143), 2010 s. 2-4.; J. Gotkowska, Niemiecko-rosyjskie konsultacje międzyrzadowe - przerost formy nad treścia?, Tydzień na Wschodzie, OSW, Nr 24(184), 2011, s. 5-7.; Rohstoffpartnerschaft mit Russland, Ost-Ausschuss der Deutschen Wirtschaft, http://www.ost-ausschuss.de/deutschland-und-russland-wollen-rohstoffpartnerschaft-vereinbaren [dostęp: 18.11.2012]; Unternehmer erleichtern Merkel die Gespräche, Handelsblatt, http://www.handelsblatt.com/meinung/kommentare/staatsbesuch-in-russland-unternehmer-erleichtern-merkel-die-gespraeche-/7399508.html [dostęp 18.11.2012]. 
Energiewende. W koncepcjach ministra środowiska Petera Altmaiera transformacja energetyczna jest również rozumiana jako narzędzie promowania wzrostu gospodarczego poprzez eksport technologii. Propozycja utworzenia klubu państw energii odnawialnej ma na celu zainteresowanie oraz wsparcie m.in. mocarstw wschodzących w przekształceniu własnej struktury energetycznej przy pomocy niemieckiej technologii ${ }^{38}$. Podobnej logice odpowiada wspieranie i propagowanie (szczególnie przez polityków FDP: ministra spraw zagranicznych Guido Westerwelle oraz ministra współpracy gospodarczej i rozwoju Dirka Niebela) projektu DESERTEC. Koncentruje się on na stworzeniu możliwości pozyskiwania energii słonecznej na północnych wybrzeżach Afryki (szczególnie w państwach: Maroku, Tunezji, Algierii) oraz transporcie jej do Europy. Zaangażowanie $\mathrm{w}$ ten program zarówno niemieckich przedsiębiorstw jak i rządu powoduje zwiększenie problematyki OZE w ramach polityki zagranicznej RFN ${ }^{39}$.

\section{Uwagi końcowe}

Przygotowanie i realizowanie koncepcji mocarstw wschodzących jest jednym z najważniejszych elementów niemieckiej polityki zagranicznej. Może ono również przywrócić większą władzę i zakres odpowiedzialności z Urzędu Kanclerskiego do MSZ (świadczy o tym stworzenie specjalnego referatu $\mathrm{w}$ wydziale 3 AA zajmującego się koordynowaniem polityki wobec mocarstw wschodzących) ${ }^{40}$. W następstwie próby skoordynowania dotychczasowych podejść do silnych państw rozwijających się koncepcja rodzi szereg pytań.

Przede wszystkim RFN opiera swoje działania na założeniu prymatu gospodarki nad innymi elementami polityki zagranicznej. Większość działań realizowanych $\mathrm{w}$ ramach omawianej koncepcji ma przygotować

${ }^{38}$ Mit neuer Energie. 10-Punkte-Programm für eine Energie- und Umweltpolitik mit Ambition und Augenmaß von Bundesumweltminister Peter Altmaier, BMU, Berlin, August 2012, s. 18. http://www.bmu.de/files/pdfs/allgemein/application/pdf/10_punkte_programm_ bf.pdf [dostęp: 18.11.2012].

${ }^{39}$ Por. Nachhaltigkeit weltweit, http://www.bundesregierung.de/Content/DE/Artikel/2011/09/2011-09-23-pieper-nachhaltigkeit.html [dostęp: 18.11.2012], Deutschland und Tunesien betonen Partnerschaft http://www.bundesregierung.de/Content/DE/Artikel/2012/03/201203-14-MP\%20Jebali\%20in\%20Berlin.html [dostęp: 18.11.2012]. Z niemieckiego punktu widzenia istotne jest również większe uznanie działalności Międzynarodowej Agencji Energii Odnawialnej (IRENA). Więcej na ten temat: S. Röhrkasten, K. Westphal, Für die deutsche Energiewende spielen. Die IRENA: Schon vergessen?, SWP-Aktuell 62, November 2012.

${ }^{40}$ Relacje te zostały zachwiane na korzyść Urzędu Kanclerskiego w wyniku kryzysu zadłużeniowego w strefie euro i były podyktowane chęcią bezpośredniego wpływu kanclerz Merkel oraz jej doradców na przebieg przekształceń w strefie euro. 
grunt pod niemieckie inwestycje zagraniczne oraz poprawić możliwości eksportu do omawianych państw.

Po drugie Niemcy są odbierane przez mocarstwa wschodzące jako „brama do Unii Europejskiej”. Większość państw z tej grupy uznaje RFN za najważniejszego aktora UE będącego w stanie przeforsować na forum dwudziestu siedmiu państw rozwiązania korzystne z punktu widzenia nowych mocarstw. Stwarza to wyzwanie dla rozłożenia unijnych priorytetów i wyważenia interesów wszystkich państw oraz unikania zapisów preferujących korzystne rozwiązania tylko z punktu widzenia partykularnych interesów pojedynczych członków.

Trzecim wyzwaniem związanym $\mathrm{z}$ mocarstwami wschodzącymi jest połączenie polityki prowadzącej do ożywienia stosunków gospodarczych z przestrzeganiem praw człowieka w państwach adresatach koncepcji, o czym szczegółowo mówi strategia niemieckiego MSZ. Dysonans pomiędzy deklaracjami, szczególnie w dyskursie wewnątrzniemieckim, a realnymi działaniami zmierzającymi do poprawy przestrzegania praw i podstawowych wolności wśród mocarstw wschodzących jest widoczny i wraz ze wzrostem znaczenia tych państw dla niemieckiej gospodarki będzie stale się pogłębiał (tendencję tę widać zwłaszcza w odniesieniu do Chin).

Czwartym elementem dotyczącym wyzwań wobec mocarstw wschodzących jest konieczność wielowymiarowych inwestycji w tych regionach. Ich brak nie pozwoli w dłuższej perspektywie na utrzymanie wysokiego poziomu niemieckiego eksportu. Niemcy podkreślają, iż są gotowe do pomocy w transformacji i reformach państw rozwijających się, co jest jednym z kluczowych fragmentów koncepcji dotyczącej mocarstw wschodzących.

Realizacja zarysowanej strategii będzie prowadziła również do konfliktów z dotychczasowymi partnerami RFN zarówno w Europie jak i na płaszczyźnie transatlantyckiej. Zasadniczym pytaniem jest więc czy Niemcy będą w stanie pogodzić chęć większego zaangażowania pozaeuropejskiego z zachowaniem tradycyjnych sojuszy i faktycznym działaniem wspólnotowym?

\section{Zusammenfassung}

Seit 1973 nahm der Einfluss Deutschlands auf die UNO ständig zu. Abzulesen ist dies vor allem am Anteil deutscher Staatsangehöriger in der UNO-Verwaltung in New York. Außerdem ist Deutschland schon drei Mal als Mitglied in den Sicherheitsrat der Vereinten Nationen gewählt worden.

Alle deutschen Regierungen nach der Wende sind der Tendenz. die deutsche Position in der UNO zu stärken, gefolgt. Sämtliche Bundesregierungen seit 1989 bemühten sich um 
eine aktive Rolle innerhalb der Vereinten Nationen, unter anderem bei der Gestaltung der UN-Agenden und -Programme. Zudem trägt Deutschland einen beachtlichen Teil zum Haushalt der Vereinten Nationen bei.

Die seit zwanzig Jahren vorbereitete Reform der Vereinten Nationen spiegelt diese neuen Machtkonstellationen und Herausforderungen nach dem Ende des Kalten Krieges wider. Allerdings erhalten die Reformpläne keine ausreichende Unterstützung seitens der UN-Mitglieder. Dies liegt vor allem daran, dass die P5 (USA, Großbritannien, Frankreich, Russland und China) unterschiedliche Interessen haben und keine große Reform der UNO anstreben.

Der nichtständige Sitz im Sicherheitsrat der UNO (2011॰2012) ist für Deutschland eine Chance zur Konsolidierung der Zusammenarbeit zwischen denjenigen Staaten, die einen Wandel der Vereinten Nationen anstreben und zur Durchsetzung weiterer Reformvorhaben. Gleichzeitig wird Berlin es innerhalb der zweijährigen Amtszeit versuchen, seinen Einfluss in den Vereinten Nationen weiter auszubauen. Dies gilt insbesondere für die Themenbereiche Afghanistan, Kinder in bewaffneten Konflikten und Klimaschutz. 